\title{
Mentoring Entrepreneurial Networks: mapping conceptions of participants in technological-based business incubators in Brazil
}

\author{
Helder Pontes Regis, James Anthony Falk, Sônia Maria R. Calado Dias \\ (Faculdade Boa Viagem, Brazil) y Antonio Virgilio Bittencourt Bastos \\ (Universidade Federal da Bahia, Brazil) $^{1}$
}

\begin{abstract}
Resumen
La agenda de la investigación reciente sobre emprendedores incluye el análisis de las estructuras cognitivas de los empresarios de éxito, revelándose como una herramienta importante a la hora de examinar una trayectoria emprendedora. Mediante técnicas de mapas cognitivos, este estudio explora los conceptos de una trayectoria de éxito y la red en sí misma como un todo, para el desarrollo de esta carrera. Fueron estudiados 53 empresarios en siete viveros tecnológicos de la ciudad de Recife, Pernambuco, Brasil. El objetivo específico de este estudio era situar los significados comunes de los emprendedores del vivero teniendo en cuenta las redes de apoyo informal. Este tipo de redes ofrecen apoyo a la carrera empresarial, y el presente estudio examina tanto las características como el modelo conceptual que subyace bajo éstas. La recolección de datos fue realizada por medio de entrevistas a través de la técnica de evocación libre. Los significados comunes indican la existencia de categorías de pensamiento inherentes que fomentan el contexto de la red en el entorno del vivero, especialmente en las redes-mentor. Los resultados refuerzan la interpretación de un modelo mentor informal que emerge de las evocaciones predominantes respecto a una carrera de éxito y de la red en sí misma como promotora de su desarrollo.
\end{abstract}

Palabras clave: cognición emprendedora - carrera empresarial - red de trabajo mentorización - mapas cognitivos.

\begin{abstract}
The recent entrepreneurship research agenda includes the analysis of cognitive structures of successful entrepreneurs, revealing an important tool for the examination of an entrepreneurial career. Using techniques of cognitive maps, this study explores the concepts of a successful career and the network itself, as a whole, for career development. Fifty-three entrepreneurs were studied, in seven technological incubators in the city of Recife, Pernambuco, Brazil. Specifically, this study aimed to map the shared meanings of the incubated entrepreneurs regarding informal support networks. Such networks support the entrepreneurial career and the present study explores the characteristics and the conceptual model that underlies the networks. The data collection was achieved through interviews through a free evocation technique. The shared meanings indicate the existence of inherent thought categories that support network context in the incubator environment, mainly the mentoring networks. The results endorse the interpretation of an informal mentoring model emerging from the dominant evocations concerning a successful career and of the network itself as promoter of career development.
\end{abstract}

Key words: entrepreneurial cognition - entrepreneurial career - network mentoring - cognitive maps.

${ }^{1}$ Helder Pontes Regis [hregis@hotlink.com.br], James Anthony Falk [thefalks@terra.com.br], Sônia Maria
R. Calado Dias [srcalado@elogica.com.br], Antonio Virgilio Bittencourt Bastos [virgilio@ufba.br]. 
The interest on social support networks can be found in literature since Durkheim's initial work (1897 / 1977). It was focused on the solidarity effects and social integration of networks on mental health. The focal point of the theories that treat social support in organizations is on the ways that communication networks can help organization members deal with stress. Wellman (1992) adopted this structure in his study on social support networks. His research is broadly based on the premise that the networks play a protective role with regard to the effects of stress on people's mental well-being.

Nowadays, literature on mentoring identifies social networks as an important aspect for an individuals' career development (Higgins \& Kram, 2001). However, it does not manage to clarify the benefits involved with relationships in the form of a network, how they are structured, or the meaning they have for people who opt to follow new career fields. The initial problem is with the fact that approaches for network studies are nearer to a methodological body of knowledge than a theoretical body. The reason for this is the scarce theoretical explanation in the studies on social networks. Another reason is the lack of connection among the cognitive, structural and relational aspects when trying to explain some social theories by means of networks. Even the researches on networks that apply theory do it without giving much attention to network mechanisms implicit in the theories. The traditional analysis of networks typically takes account of only relatively simple and superficial characteristics, ignoring the more sophisticated and subtle symbolic structures inherent to many networks that depend on more profound investigation for revelation.

Besides the structural position occupied by the actors of certain social networks, the way they behave is also influenced by their cognitive maps. The support that incubated entrepreneurs seek through the network is operationalized, above all, when meaning shearing exists with regard to the transacted contents aimed at career development. The effective transaction of resources, therefore, is also related to meaning sharing among the support network actors. The interest on this cognitive dimension is sustained on the supposition that support relationships, in the context of incubated ventures, could occur through a network formed of various mentors (Higgins \& Kram, 2001). In other words, mentors and entrepreneurs develop individual mental models as well as collective, and these models, besides being modified by the individuals of the network, are also influenced by their socialization through the network. 
Thus, this study seeks to go further into the entrepreneurial area than research developed up until now (Mitchell et al., 2002), by means of the application of the knowledge on social cognition and network relationships. In this study, the need to create and to keep mentoring relationships will be considered as fundamental for the development of entrepreneurial careers of the participants within incubated processes.

Typically, researchers have studied the forms of incubation, resource availability, partnerships, and even chains of enterprises as a way for unveiling the learning processes in the incubator context. In this study, in order to contribute to theoretical knowledge, established arguments are reviewed and empirical evidence is sought regarding social cognition in the technological incubation field.

For the full comprehension of the social construction of mentoring networks, a greater integration between the literature concerning social networks, mentoring and social cognition in the context of new work relationships is necessary. However, we know little concerning the informal relationships of support to new entrepreneurs. The entrepreneurial phenomenon and the increasing number of technological-based business incubators are demonstrations of the changes in their environments. In this perspective, this study seeks to describe the shared meanings among entrepreneurs by means of enunciations, or evocations, on an successful entrepreneurial career and on the role of the network in the development of this career.

\section{Theoretical foundation}

The learning capacity of incubated entrepreneurs and their ability to share the knowledge generated in this learning process derive from a series of factors, including a special easiness that they have for the transformation of scientific knowledge into tacit knowledge (Nonaka \& Takeuchi, 1997; Spender, 1996). Moreover, they have the capacity to structure and coordinate different forms of cooperation that provide access to expertise (Conner \& Prahalad, 1996). Nevertheless, unregarding the substantial insights on the attributes of the entrepreneurs participants in technological-based incubators to get support and share knowledge, there is a lack of theoretical development for the comprehension of these capacities that are not approached in the traditional theories on entrepreneurship. Before beginning with the cognitive criteria that support the analysis of informal social networks, the entrepreneurial career itself is described. This permits a better comprehension of the shared meanings of entrepreneurs participating in a technological incubator. 


\section{Entrepreneurial Career}

New career fields are being developed, mostly as a result of the development of new information technologies. These fields lack definitions and specifications of terms used. The traditional career, in average and big size companies, has been more and more substituted due to other types of relationships between capital and work, generating new career field, for example, the "entrepreneurial career" (Mayrhofer et al., 2002).

A theory on career development is evolving almost exclusively in the organizational context, seeking to understand conflicts and challenges that people face when they assume corporate hierarchical roles. Since incubated entrepreneurs begin their career with the command of the organization, the approach on corporate careers looses its reference in this context.

On the other hand, researchers on entrepreneurship have studied the factors that motivate people to initiate their own business. Historically, a study of entrepreneurship has strived to articulate individual factors what influence people to embark on an entrepreneurial adventure. (Sexton \& Bowman, 1984). Due to the emphasis on the factors that influence someone to initiate a business, given by researchers on entrepreneurship, little effort has been given to understand how these people develop different roles along their careers. The study of entrepreneurship appears to be imprisoned to its end results, that is, a new business was opened and the performance was positive or negative. Researchers have given strong emphasis to the areas in which a career possesses well defined steps, based on roles, socialization and entrepreneurial practices (Dyer J r., 1994).

While some theories on career development see a career as only in terms of a job that someone performs, (Arthur; Hall \& Lawrence, 1989), an entrepreneurial career is greatly influenced by what is occurring, for example, in personal and family environments of a specific person. (Dyer Jr., 1994). Schein (1978) considers a career to be a social anchor point from which a person goes through life, promoting interactions between work and family and with his personal life in general. This type of approach to career development provides the broader context that is necessary in order to study entrepreneurial career development. 
Studies have pointed out the gaps left by the results that try to associate personal traits to entrepreneurial behavior (e.g. Gartner, 1988). Some authors have noted that attitude measures may be more predictive of entrepreneurial behavior than psychological traits (Robinson et al., 1991). Other authors suggest that the cognitive structuring and processes are significant factors in career choice (Shaver $\&$ Scott, 1991).

With regards to the support necessary for entrepreneurial career development, recent advances in research on mentoring show evidence that mentoring processes do take place in incubator environments. These processes occur principally through mentor diversity and by means of informal networks of development (Regis, 2005).

The analysis of social networks constructed by new entrepreneurs is more of a tool for the comprehension of how entrepreneurs connect information and resources to help in their career development. After explaining the theoretical bases in which the entrepreneurial career is involved, the following section presents the variables that make up the mentoring function.

\section{The mentoring processes}

Formal mentoring program are among the planned change interventions with the object of promoting personal development and the consequent rise in organizational efficacy. The first publications of the theory that provided support for these interventions, at the beginning of the $70 \mathrm{~s}$, were directed to the area of organizational behavior (Levinson et al, 1978). Levinson et al (1978 p. 97), when treating the corporative context, proposed that a mentor is "normally a person much older, more experienced and mature [...] a professor, councilor or godfather." The mentored person, in contrast, is the one benefited by the experience, maturity and protection of the mentor.

According to Kram (1985), mentoring assures not only personal growth but career progress as well. He summed up mentoring functions as being convergent in two principal categories. First there those relational aspects that guarantee the learning of the professional roles an individual must assume in the organization and that prepare him to reach higher positions within it. In second place there are the psychosocial functions, those aspects of a relationship that guarantee a sense of competency, that clarify the identity and affectivity of the professional role. Some examples of variables that compose the mentoring function are presented in Figure 1. 


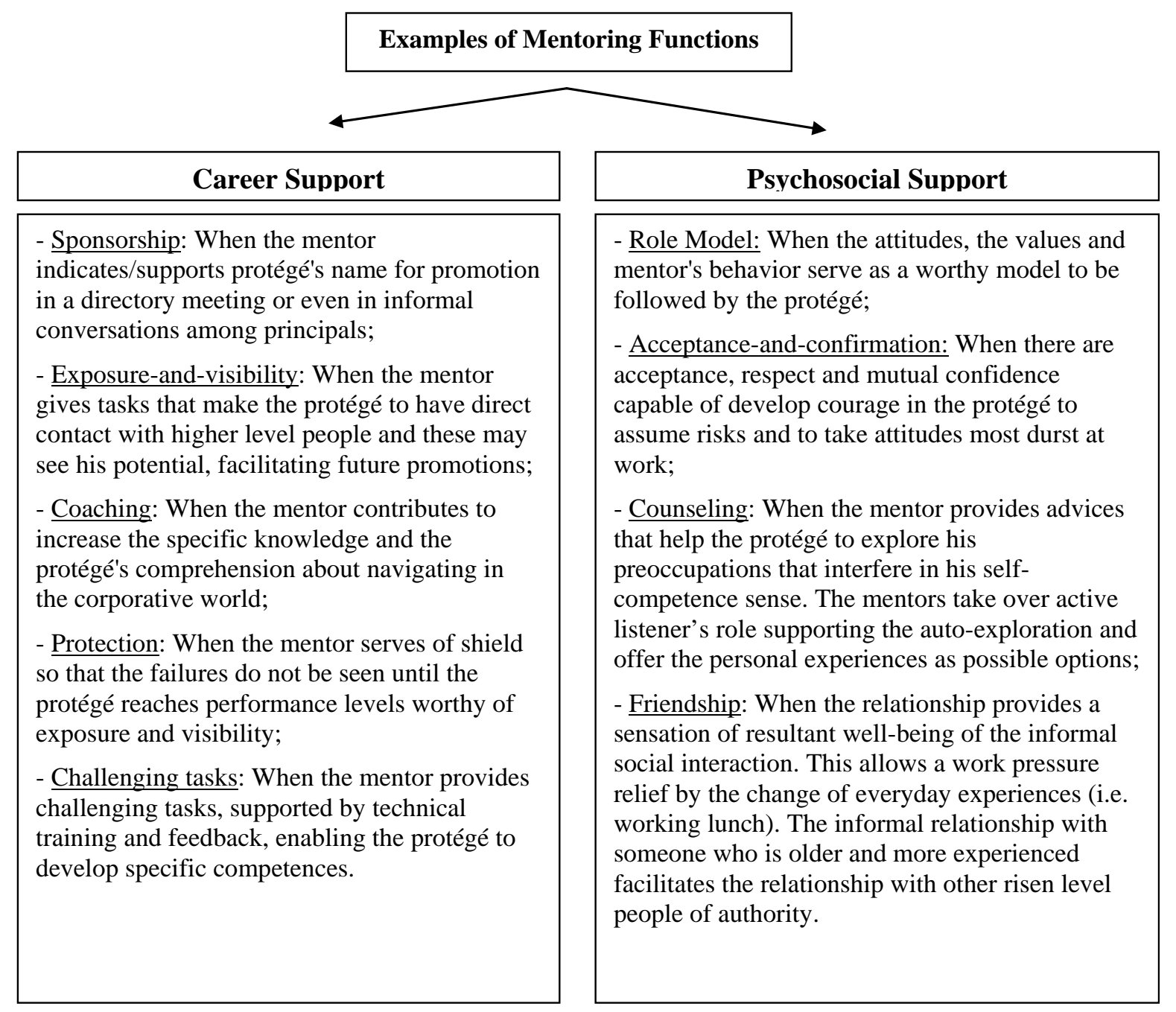

Figure 1. Examples of Mentoring Functions (Kram, 1985)

In the corporate context, career functions serve primarily to guide functional progression within the organization, while the psychosocial functions affect each person individually by the formation of a sense of self-value and operate internally as well as externally to the organization. Together, these functions capacitate the person to face the challenges of each stage of his career.

Needless to say, the basic development functions provided by mentoring, career functions and psychosocial functions (Kram, 1985) operate within different environments as well, not restricted to the corporate environment. These functions may operate, for example, in a small business, providing not only learning abilities, knowledge of policy and social rules as well as the sense of competency, of identity and of professional affectivity. 


\section{Mentoring in the context of new work relationships}

Sullivan (2000) considers that the functions of mentoring can operate within the corporate environment as well as in the environment of the self owned business. However, given that the entrepreneur, manager of his own business (mentored), does not have aspirations with regards to hierarchical levels, many of the activities of the mentor related to career development are considered as irrelevant when the mentor assumes the role of the entrepreneur's godfather. As such, the common vision of mentoring simply as a "strategy for helping the mentored to progress hierarchically in the organization" (Eby, 1997; p. 127) can not be applied to people who are starting their own business.

In this study the attention is on mental models that the incubated entrepreneurs use to simplify reality. It seeks to understand how they connect information that helps them to develop an entrepreneurial career through resource procurement, or support their network of relationships.

After discussing the theoretical bases that involve the entrepreneurial career and the processes of mentoring, the following section begins with a presentation of the cognitive dimension that underlies the informal social networks in the incubator environment.

\section{Analysis of informal social networks by means of a cognitive dimension}

The cognitive dimension assumes a fundamental role in the comprehension of the construction of support networks for incubated entrepreneurs. In the case of entrepreneurial cognition, a review of the theoretical bases is necessary to better explain the actual work related changes taking place. One can expect that the structural and relational dimensions that participate in the generation of behavioral change within network relationships should be intimately related to cognitive dimensions (Regis, 2005). The cognitive dimension is represented by meaning sharing within the network. The learning strategies used by the incubated entrepreneurs can be considered as facets of the cognitive dimension that also participate in the generation of behavioral change. These questions will be treated next.

Seminal studies in the area of entrepreneurship have applied the concepts of cognitive science and are grouped by Mitchell et al. (2002) in the area of entrepreneurial cognition. These studies have contributed to the understanding of information processing and of management cognition with relevant contributions to 
the literature in the specific area of entrepreneurship. The authors clarify that the studies on this subject are not totally explored when treating social cognition, management cognition and information processing. There is, therefore, a necessity to expand the horizons of study in these areas by means of an agenda setting for research in entrepreneurial cognition.

Due to the relatively recent preoccupation of academia on understanding how selfowned business managers think and make decisions, there is a definite need for the development of definitions and concepts that involve cognitive theory in the field of organizational psychology.

Bastos (2001) demonstrates that a large part of the literature on "cognition and organizations" focus the centrality of processes and cognitive structures on the dynamics of relational and power networks that constitute the organization. The social dimension of human cognitive processes results in a specific area of research in Social Psychology, where interests lie in the processes used by people to generate knowledge and the comprehension of the daily aspects of life. In this sense, the "social cognition" rescues, scientifically, such topics as: the processes of attribution, formation of impressions, stereotyping, attitudes, prototypes, schemes and scripts.

Such a rescue amplifies the comprehension and the balancing of conflict episodes in the formation of strategies, in the analysis of environments, in the decisions on technological innovation, in the creation of learning environments, in design planning and in organizational performance itself. (Bastos, 2000).

Rousseau (1997) emphasizes the link between the accentuated process of change through which organizations are going and the conceptual transitions that impose the study of organizational behavior. The organizations being seen as a "process" demonstrates a particular attention to group level, social networks, management cognition, meaning construction, organizational sense-making, among other topics. In other words, the author portrays the organization as a social construct.

Being such, the field of organizational study also suffers from the influence of this movement that alters concepts and suppositions that have been the foundation to organizational processes, considered here as involving the collective actions of individual around specific objectives. Following, some definitions of cognitive maps are presented. 


\section{Cognitive maps and the processes of social cognition}

Weick and Bougon (1986) present the notion of "cognitive maps" as a metaphor for the analysis of the nature of the "organization" phenomenon. The authors affirm: "Organizations exists basically in the mind, and their existence takes the form of cognitive maps. Therefore, that which unites an organization is the same thing as that which links it to, or places it near, thoughts" (Weick \& Bougon, 1986: 102).

Nearly half a century ago, Zajonc and Wolf (1966) demonstrated that the members of an organization seek different interests. The maps or cognitive structures represent models or organizational theories that are internalized in people. These models guide the analysis of organizational situations and their subsequent actions.

Cognitive maps are tools for verbal data representation (oral or written information that express affirmations, predictions, explanations, arguments, rules) by which one gains access to internal representations and to cognitive elements (images, concepts, causal beliefs, theories, heuristics, rules, scripts, etc.) (Laukkanen, 1992). Bastos (2002) further explains that the maps can give access to a respondent's suppositions, even when they are not visible to the participant himself.

Nicolini (1999) presents cognitive mapping as one of the possible strategies to represent social cognitions: "Maps can be considered only as descriptive instruments and representations that help in the discussion and analysis of some thought models and explanations of certain events" (p.836). In this way, the job of cognitive structure mapping involves "exploring the manners by which representative entities are united, transformed or contrasted" (p. 836).

Bastos (2002), gives an explanation of the methodological aspects that make the techniques of cognitive mapping an important tool for the investigation of organizational processes in symbolic, communicative and hermeneutic dimensions. They are pictured in a plurality of presentations and graphic forms.

In an attempt to organize the diversity that characterizes the capture of cognitive mapping, Huff (1990) proposes a continuum in which on one extreme the maps that evaluate attention, association and cognitive content importance are represented and capture the manifest material; and on the other extreme are the maps that specify schemes, chartings, and perceptual codes with an elevated degree of interpretation on the part of the researcher. Between the two extremes are the maps that describe categories and taxonomies, the causal maps and the 
maps that describe thinking and decision structures. These maps have already been studied by national authors in the organizational field (e.g. Bastos, 2000/2002; Machado-da-Silva et al. 2000). Fiol and Huff (1992) define them as:

I dentity Maps: those based on content analysis to identify concepts and central discussion themes in individual enunciations. They point out the principal characteristics of the cognitive terrain and the activities involved in their construction are the bases for all the other types of maps.

Categorization Maps: those that seek to describe the schemes utilized by managers to group events and situations based on resemblances or differences, having access to the thought categorization system applied and to the hierarchical dimension that exists among these concepts.

Causal Maps: the ones most publicized in management studies and which furnish the comprehension of the links that individuals establish between actions and results along time.

The identity maps are adopted in this study to capture the significance shared by the incubated entrepreneurs with relation to their successful entrepreneurial career and on the role of the network in the development of the career. The techniques utilized to establish these maps are described in the chapter on methodology.

Baron (1998, 2000) and other researchers (Baum, Locke \& Smith, 2001; Shane, 2000) have strived not only to increase methodological rigor, but create conceptual links between entrepreneurship and cognition. The psychological constructs and methods employed in these studies are relevant to the comprehension of entrepreneurial characteristics and activities.

As may be observed, the cognitive dimension of relational networks involves significance sharing. This permits the existence of a mutual recognition network, institutionalized in a social field. In practice, the significance sharing occurs as a result of individual interactions in a social structure with its own characteristics. The following section discusses the study methodology under this perspective.

\section{Empirical Study}

The research problem reared the following study questions: Considering the cognitive dimension of relational networks, how do incubated entrepreneurs organize their cognitions with relation to their successful entrepreneurial career and with regard to the role of the network in the development of this career? 
Guba and Lincoln (1994) consider that a research paradigm constitutes a system of basic beliefs, that being a vision of the world that guides the investigator. When assuming this definition of a paradigm, they also admit that the object of research, problems studied and the method of data collection and analysis will be, inevitably, influenced by this same world vision. According to the same authors, this is so because the system of beliefs is based on ontological, epistemological and methodological suppositions by means of which the investigators explain their concepts of world nature and of the place occupied by individuals.

Having observed these questions, a basic qualitative research was selected. It is characterized as such since it seeks to describe, categorize, characterize and interpret the constructs utilized by the incubated entrepreneurs (Guba \& Lincoln, 1994; Creswell, 1994; Mariz et al., 2005).

\section{Locus of the investigation}

The population of incubated entrepreneurs in Recife, in the technological area, who have active businesses, is approximately 80 individuals. There are a total of 41 businesses installed in seven incubators. Although a qualitative study does not follow a sample procedure, but that of replication, where some replication of results is sufficient to finalize the data collection, (Yin, 2001), a non-random sample was taken. Even though various replications occurred, the data collection progressed, seeking to study the largest number of incubated entrepreneurs as possible. Sixtysix percent of the population was studied. Fifty-three incubated entrepreneurs participated in the research from 27 technological-based business. This number provides a greater degree of representation to the findings.

\section{Techniques for the construction of cognitive mapping}

The cognitive dimension was captured by means of semi-structured interviews. In these interviews, the entrepreneurs were asked to freely evoke their ideas with relation to their successful careers and to the role of the network in their career development.

The verbal material produced by the incubated subjects resulted from a process known as "schematization" (Bastos, 2002). To determine the central and peripheral elements of these two concepts, both quantitative and qualitative approaches were utilized.

The technique applied consisted in requesting that each entrepreneur freely talk on whatever came to his mind, initially in relation to his successful entrepreneurial 
career, and then with relation to the role of the network in the development of his career. While the entrepreneurs talked, the researcher transcribed short phrases to describe each idea formulated up to the limit of twelve enunciations. When the ideas on each concept were finished, the enunciations that had been registered were presented to the entrepreneurs so that they could rank them in level of importance. The ranking done by each one, from a list of their own evocations, permitted the identification of the relevant constructs involved. (Sá, 1998; Vergara, 2005).

From the enunciations suggested by the interviews, a content analysis was performed to identify the units of analysis that were repeated by the study subjects. The product obtained from the free enunciations was analyzed by means of a four quadrant technique (Fischer et al., 2003; Vergara, 2005). This technique, combining frequency and the average order of evocation, permits the distribution of terms produced according to the importance attributed by the research subjects. Along with this, it shows to be an instrument that facilitates the structural and organizational analysis of shared significance among the entrepreneurs. Therefore, the force of each enunciation was defined by the frequency and the median order of occurrence. (Ex: the enunciation "financial return" occurred 17 times with a average order of 3,5; approximately in 4th place). The SPSS software was used to calculate frequency and average order of occurrence of the evocations. The procedures for the construction of cognitive maps follow.

After content analysis, the data were grouped into larger categories, in the form of cognitive maps. Regardless of the graphic help provided by this software in the organization of data, the choice of categories is subjective. This means that the investigator must seek to associate the enunciations to context and end up using theoretical filters when trying to interpret the "realities" expressed by the entrepreneurs, grouping them into distinct categories. The shared cognitive maps provided by the entrepreneurs, for each of the two concepts studied are shown in the following paragraphs.

\section{Results}

The shared significance of the entrepreneurs regarding their successful careers and with relation to the role played by the network in career development was analyzed from the salient content of their enunciations. The data treated by the four quadrant technique resulted in the identification of the central elements of the incubated entrepreneurs interviewed. (Fischer et al., 2003; Vergara, 2005). In this 
technique, the first quadrant expresses the truly significant terms and constitutes the central nucleus of the shared significance of the incubated entrepreneurs. The results found from the fifty-three entrepreneurs interviewed are provided in the following.

\section{Shared significance on successful careers}

The first quadrant provides the enunciations of central level. These enunciations obtained the largest frequency and average order of evocation (AOE) closest to one (1st place) in the speech of the entrepreneurs. These evocations also form a group of the more stable enunciations - Chart 1 . The other three quadrants serve to show the frequency and the average orders of the intermediate and peripheral evocations. These evocations are presented as cognitive maps, however, no distinction is given as to the positions occupied (intermediate or peripheral). It should be remembered that the evocations on Chart 1 (strongest force) are also presented in the following cognitive maps with distinction given by the use of boldface - Figures 2, 3 and 4 . These maps reveal the categories used by the entrepreneurs in shared significance.

\begin{tabular}{|l|c|c}
\hline Evocations of central nucleus concerning the successful career & $\begin{array}{c}\text { Average. } \\
\text { Order } \\
\text { Evocation }\end{array}$ & Freq. \\
\hline Financial return & 3,5 & 17 \\
\hline Recognition - recognized enterprise & 3,8 & 16 \\
\hline Professional autonomy & 3,3 & 11 \\
\hline Satisfaction & 2,6 & 9 \\
\hline Personal and professional accomplishment & 2,2 & 9 \\
\hline Knowledge - Search of information & 3,5 & 8 \\
\hline Benchmarking & 3,6 & 7 \\
\hline Financially comfortable & 2,8 & 6 \\
\hline Quality of life & 3,4 & 5 \\
\hline Effort - hard work & 3,2 & 5 \\
\hline To do and make what I like & 2,6 & 5 \\
\hline High quality products and/or high quality services & 2,4 & 5 \\
\hline To assume responsibilities & 3,8 & 4 \\
\hline Qualification & 2,8 & 4 \\
\hline Improvement - Standardization of the processes & 2,5 & 4 \\
\hline
\end{tabular}

Chart 1. Evocations concerning the success career with $\mathrm{AOE}<3,9$ and Frequency $>3,1$

The idea or vision that the entrepreneurs have with regards to their successful career was evaluated positively and is associated primarily to the success of their business and personal success. The existence of some dilemmas that the entrepreneurs had to face was also salient in the enunciations, such as the fact of 
having to assume responsibilities. The cognitive map on successful careers characterizes the incubated entrepreneurs, furnishing a general panorama of the statement contents, providing important information on the cognitive dimension of the support received through the relational network.

The cognitive map that provides a graphics form of the shared significance of the incubated entrepreneurs with regards to a successful entrepreneurial career follows. Due to the limit of space, the map is divided into three parts: initially, Figure 2 presents the basic category of the statement contents registered.

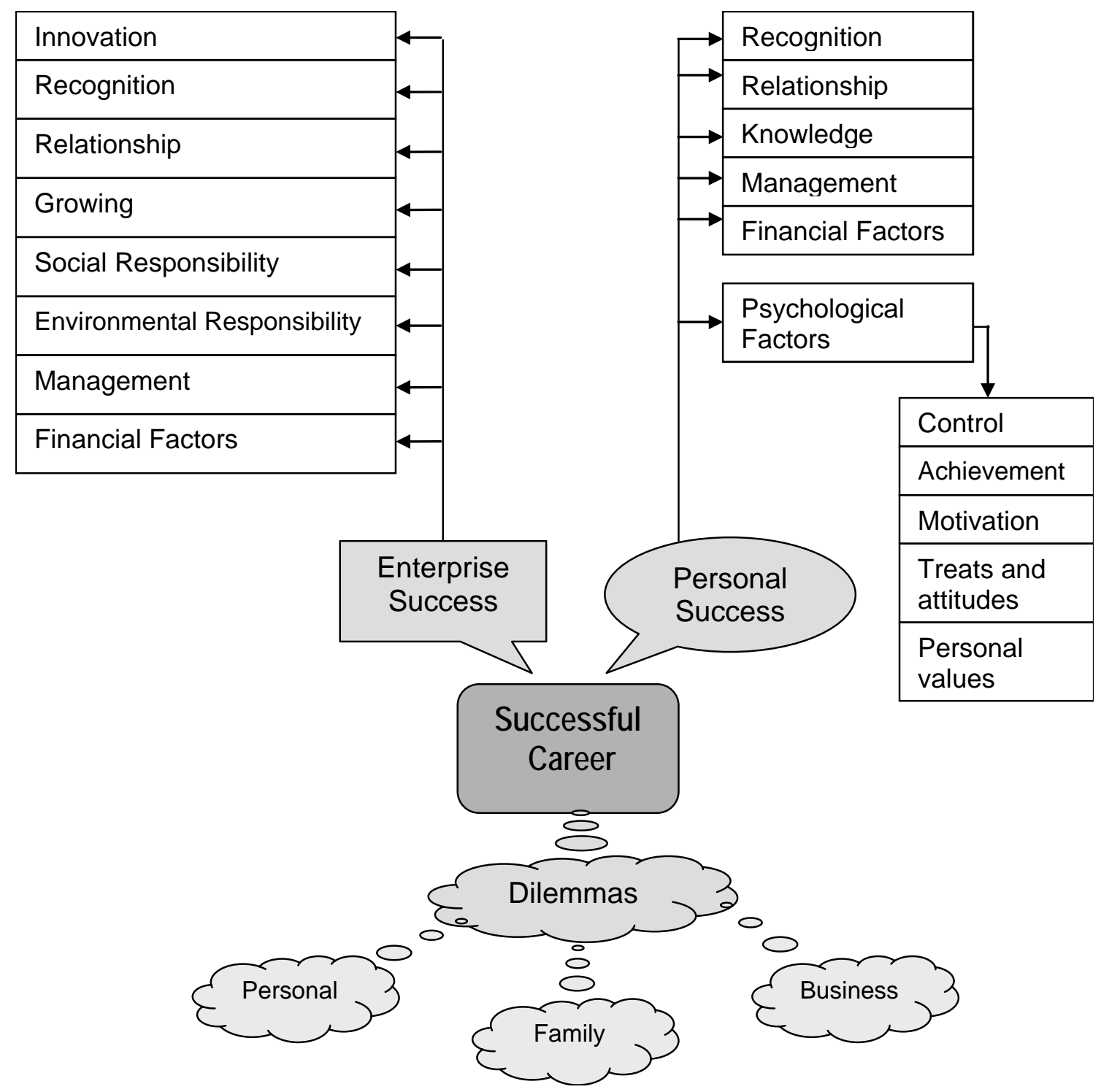

Figure 2. Map of the basic categories with regard to a successful career 
This map records the basic categories and is further divided into two parts Figures 3 and 4 - that provide the evocations given by entrepreneurs on a successful career. The statements emphasized by boldface are the evocations of greater statistical strength, or the central nucleus, already presented in Chart 1.

The left side of Figure 3 demonstrates the evocations that regard "success in the business" and "dilemmas". These two concepts compose categories shared by the entrepreneurs interviewed with regards to a successful career.

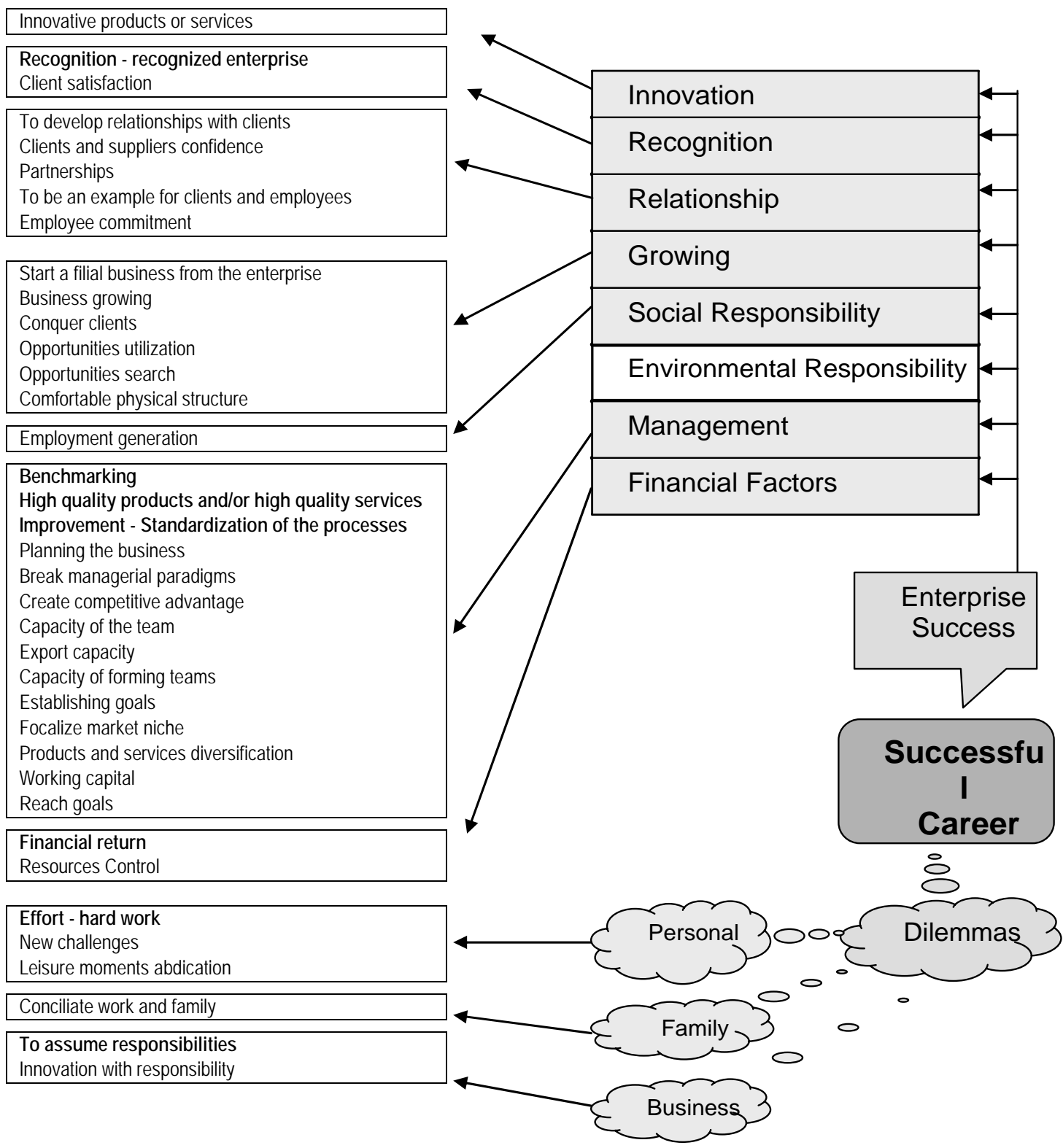

Figure 3. Evocations concerning the successful career categories: Enterprise success and Dilemmas 
The right side of Figure 4 shows the evocations that treat the category "successful person". This concept composed the last basic category shared by the entrepreneurs with regards to a successful career. It is worth emphasizing the category "Motivation" without evocations.

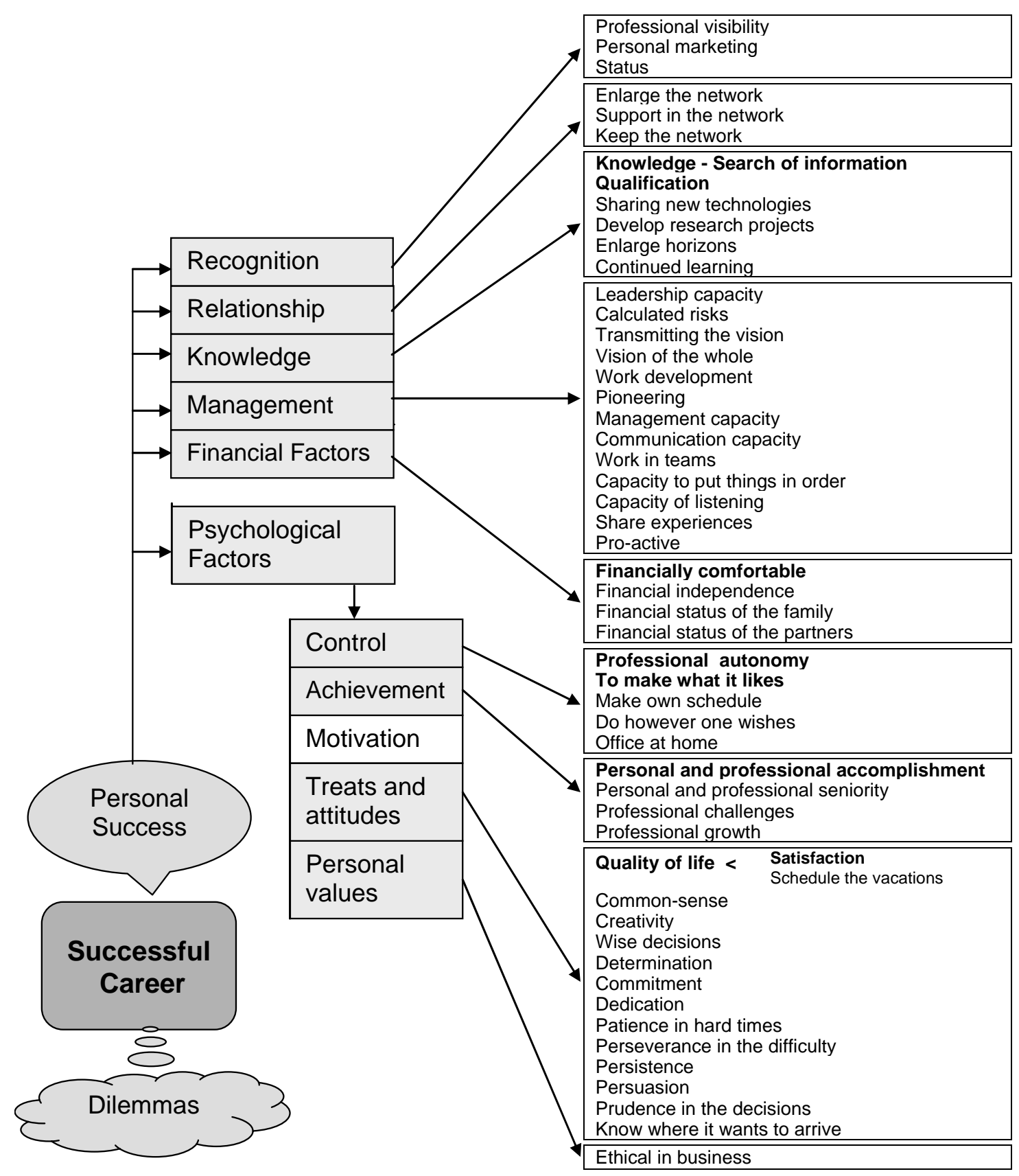

Figure 4. Evocations concerning the Personal Success 


\section{Shared significance on the role of the network}

Initially the Chart that comprises the central nucleus is shown, or rather, the group of more stable evocations on the role of the network with regards to career development - Chart 2 . The intermediate and peripheral evocations that compose the other quadrants are presented in the cognitive map.

\begin{tabular}{|l|c|c}
\hline \multicolumn{1}{|c|}{$\begin{array}{c}\text { Evocations of central nucleus concerning the role of the } \\
\text { network to the career development }\end{array}$} & $\begin{array}{c}\text { Avarage } \\
\text { Order } \\
\text { Evocation }\end{array}$ & Freq. \\
\hline Opportunities for new businesses & 2,2 & 26 \\
\hline Encouragement and emotional support & 2,6 & 19 \\
\hline Indications & 2,7 & 11 \\
\hline Exchange of experiences and "know-how" & 2,7 & 10 \\
\hline Increase the contact with other people & 2,6 & 10 \\
\hline Visibility with credibility & 2,1 & 9 \\
\hline Customer network increasing & 2,3 & 6 \\
\hline Feedback & 2,8 & 5 \\
\hline To maintain relationships & 2,4 & 5 \\
\hline To be able to transfer knowledge & 1,6 & 5 \\
\hline
\end{tabular}

Chart 2. Evocations concerning the network role with $\mathrm{AOE}<2,9$ and Frequency $>4,3$

The cognitive map that provides a graphic view of the shared significance on the role of the network in career development follows. This map is also divided into three parts: initially - Figure 5 - the basic categories of the contents evoked are pictured. The next map contains the basic categories and is divided into two parts Figures 6 and 7 - that portray the evocations by the entrepreneurs on the role of the network. The statements emphasized in boldface are also evocations of larger statistical significance, or the central nucleus, presented in Chart 2.

The cognitions evoked appear congruent with the career and psychosocial functions of mentoring (Kram, 1985). Besides this, the categories "opportunities" and "facility in the access of specialized resources" are presented as being specific to the context studied. The results point to significance sharing on the role of the network with regards to career development among the incubated entrepreneurs. 


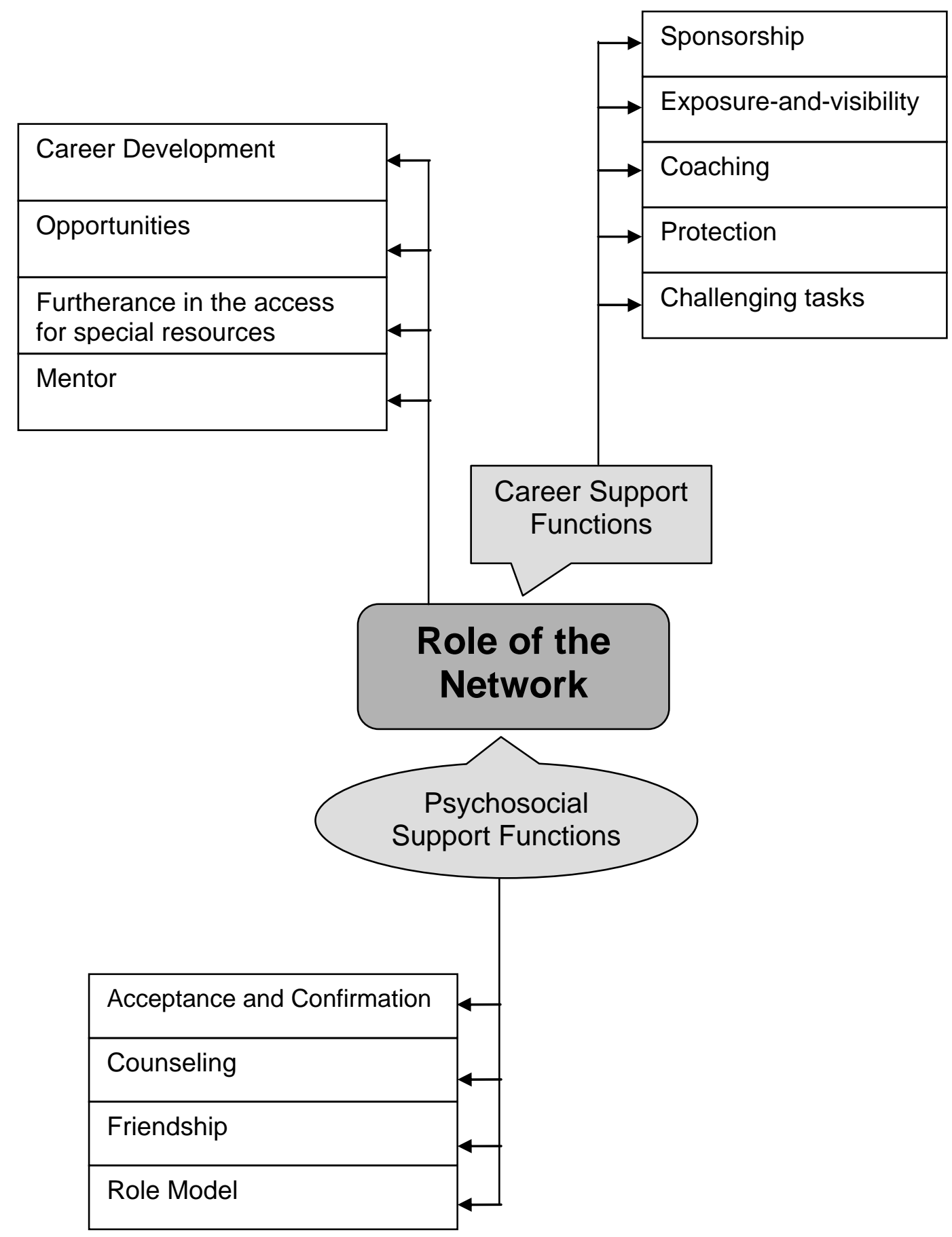

Figure 5. Map of the basic categories with regard to the role of the network to the career development

Figure 6 presents, on the left side, the evocations that regard the categories of "Career Development", "Opportunities", "Furtherance in the access for special resources", "mentor" and "psychosocial support functions". These concepts compose the first shared categories with relation to the role of the network in career development. It is worth emphasizing the category "role model" without evocations. The evocations with frequency equal to 1 may be unconsidered in this type of analysis (FISCHER et al., 2003). However, they were preserved with the 
intention of permitting the confrontation of these results with future research on incubated business of technological basis.

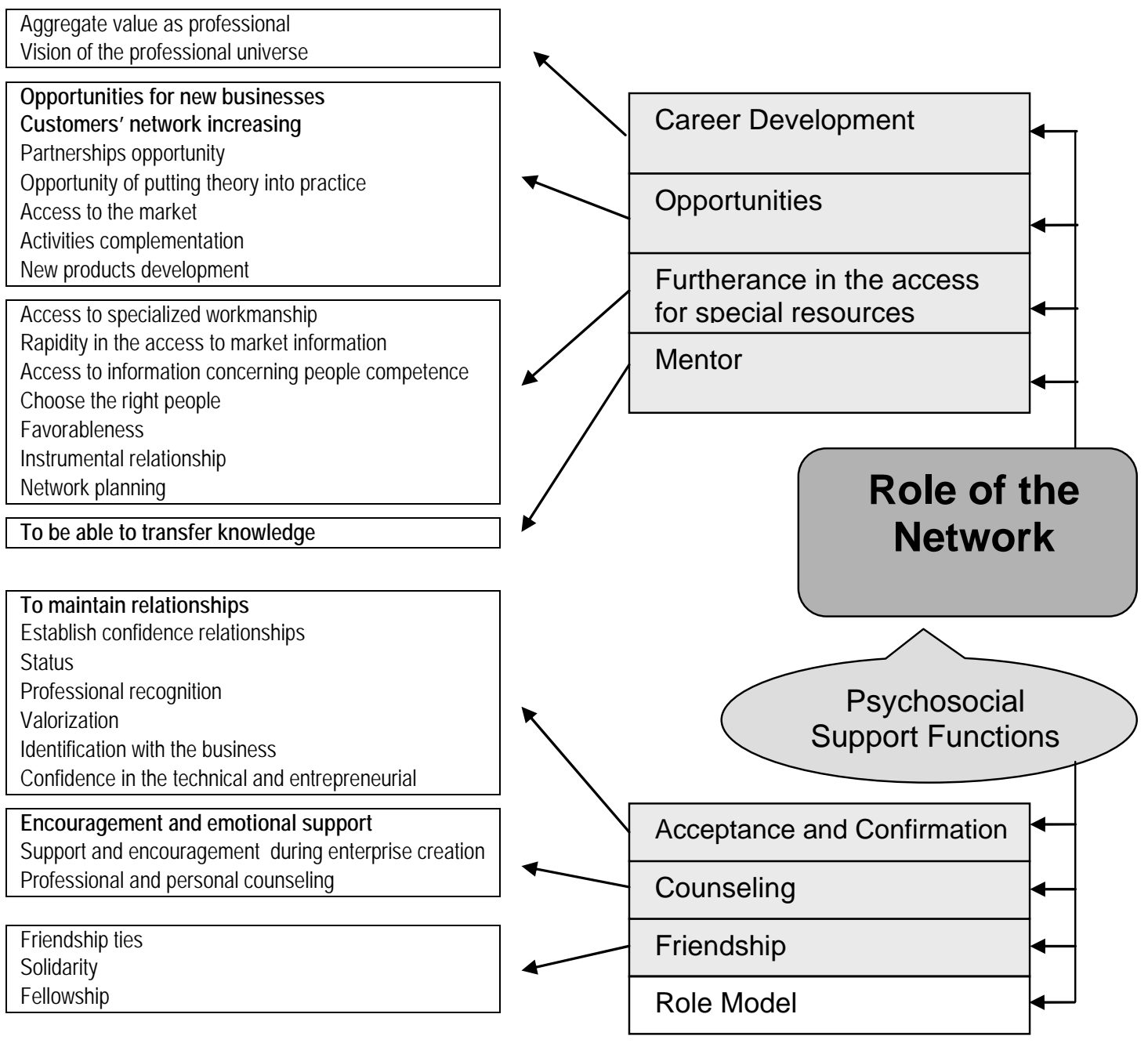

Figure 6. Evocations concerning some specific categories and the Psychosocial Support Functions categories

The right side of Figure 7 shows the evocations that treat "career functions". This concept composes the shared category of the role of the network in career development provided by the entrepreneurs interviewed. It is worth emphasizing the categories "Protection" and "Challenging tasks" without evocations. 


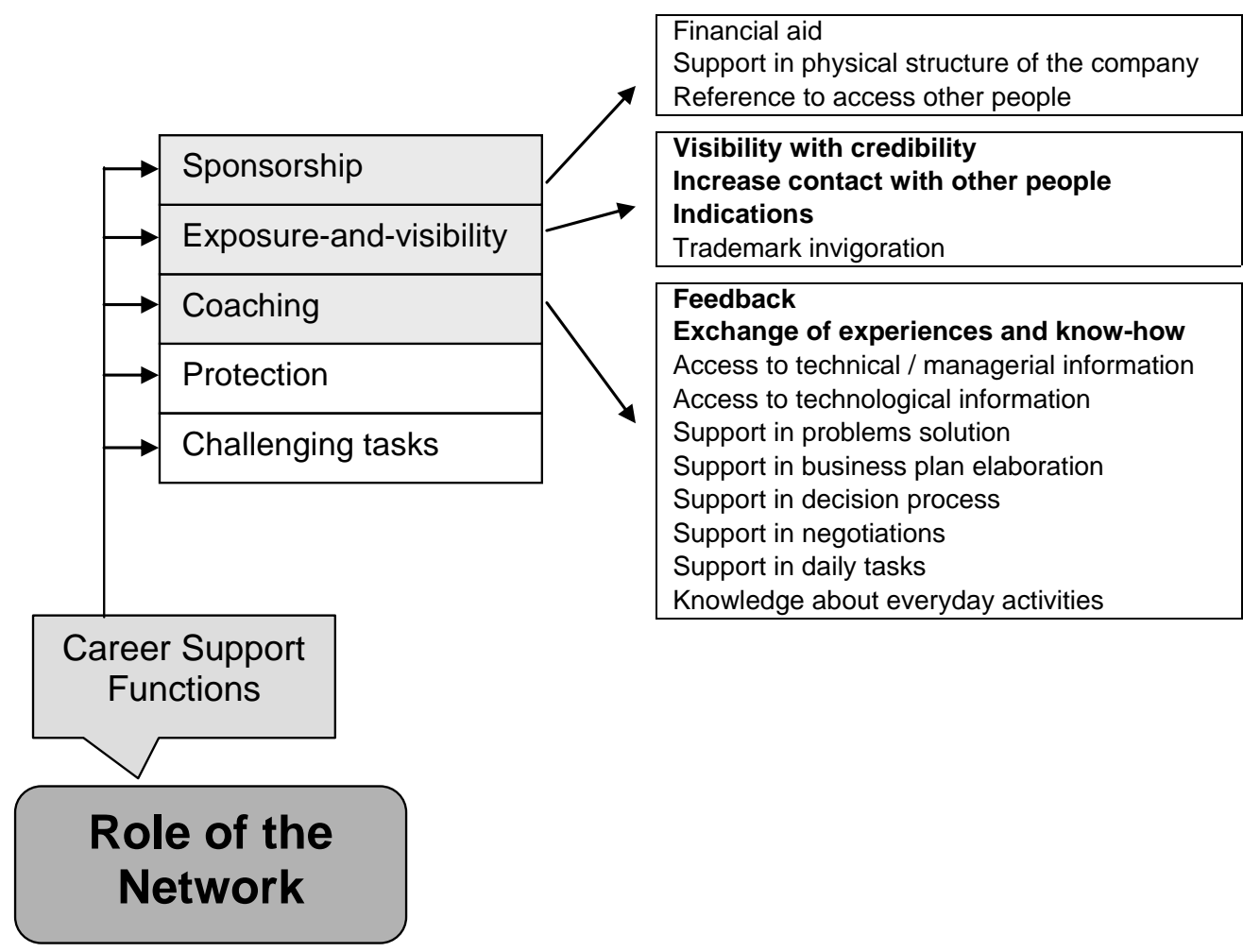

Figure 7. Evocations concerning Career Support Functions categories

\section{Discussion and conclusions}

Allocation is the process by which people that receive information, external to their own areas of expertise, determine which persons in their network can receive this information, redistributing it (Monge \& Contractor, 2003). Organizational studies have treated these cognitive processes studying the attributes, or the relationships, of these individuals (Higgins \& Kram, 2001). However, this study observed that these productive mechanisms may also be part of a transactional system contained in the maps socialized by the incubated entrepreneurs. In this sense, the socialized maps have emerging properties, such as knowledge and experience differentiation, that can be transacted through the incubated network.

The support obtained in the incubated entrepreneurs' individual network was differentiated from the organizational support derived from the relationships the incubated entrepreneurs develop daily with clients, vendors, suppliers, partners and fomentation organs, for example. This differentiation was observed not only in the socialized map regarding the successful career but in the socialized map regarding the network role for the career development as well. 
From the task of categorizing their own statements, the entrepreneurs explicated their thoughts with regard to individual success as well as company success. In the cognitive map concerning the role of the network, the main category that related to organizational scope was "exposure and visibility". Those related to individual scope were "acceptance-confirmation and counseling".

The support obtained from the incubated individual network has the property of being a private good, while the organizational support can be considered as being of public nature. Considering the support as a public good, the incubated entrepreneurs can have access to the resources derived from the organizational network, without necessarily directly taking part in the construction of those relationships (Kostova \& Roth, 2003). It was possible to note that these two support levels are frequently interrelated. For example, an incubated entrepreneur, through his relationships (Figure 6 - Role of Network: Opportunities), can establish an agreement with another company. In this case, the organizational support was created from the individual network.

As the cognitive map on a successful career (Figure 3 - Successful career: Enterprise success: Financial factors) showed that "financial return" can be considered a statement of central nucleus, it can also be suggested that business men may consider their relationships as competitive. This aspect was drawn from the fact that the category "Relationship" (Figure 4 - Successful career: Personal success: Relationship) does not present evocations with central nucleus. Specifically, the evocation "Keep the network" was positioned among the peripheral evocations, with only two evocations. This may generate the motivation to abandon the relationship with clients, or distant partners, after enough resources or support have been obtained for a certain career advance, not opting for a long term relationship. On the other hand, this did not occur in the map on the Role of the Network, leading us to believe that in closer relationships, the maintenance of the relationship itself is fundamental. This was evidenced by the fact that the evocation "To keep relationships" was a statement of central nucleus in the category "Acceptance and Confirmation" (Figure 6 - Role of the Network: Psychosocial Support Functions: Acceptance and Confirmation).

The incubated entrepreneurs showed readiness not only to seek but to share knowledge in order to improve career development. The knowledge search was evidenced in the shared map on successful career by the central nucleus statement "Knowledge - Search of information" and "Qualification" (Figure 4 - Successful Career: Personal Success: Knowledge: Knowledge - Search of information). In the 
map on the Role of the Network the disposition to share knowledge is evidenced from the central nucleus statement "To be able to transfer knowledge". This statement was put in a specific category, where an entrepreneur may also be a mentor, not only a protégé and therefore, may put in practice all or part of Kram's mentoring functions. The option was to allocate this statement to the category "Mentor" (Figure 6 - Role of The Network: Mentor: To be able to transfer knowledge).

The entrepreneur's central nucleus evocations also revealed a preoccupation with benchmarking, with product quality and with process standardization, which characterizes a preoccupation with the mimetic processes. This was revealed in the category "Management" (Figure 3 - Successful Career: Enterprise Success: Management) showing that, besides worrying about innovation, the incubated also worry about following the best practices of other organizations, or in imitating those companies with good reputations. Isomorphic pressures for legitimizations also influence the entrepreneur's intent to be involved in similar networks, according to his business activity. Thus, there is content transaction taking place when the entrepreneurs share, through their cognitive maps, interaction logic (Inkpen \& Tsang, 2005). This logic is derived from the belief that there is value aggregation to the services, to the company and to the career of the incubated through the cooperation and support obtained in the network.

The cognitive maps showed that informal connections can facilitate resource and information transference among incubated entrepreneurs, in order to accomplish objectives that are instrumental as well as collective. The transacted resources can be: the feedback that flows among entrepreneurs, or the confidence that flows among them regarding confidential information, generating the social support that flows among them. Due to the risk in technological information exchange, a confidence relationship may be necessary. In this relationship there are implicit rules and languages that are shared by the actors. In other words, codes of accepted conduct exist among them.

When concluding this study, the need for investment in business men's incubated relationships could be observed. The support obtained through the network depends on significant investment, so that relationships can be constructed and maintained. Therefore, investments in training in technological and managerial areas should be accompanied by investments to facilitate the social construction of informal networks among entrepreneurs, mentors, professors, managers, financial suppliers, and so on. 
The government and fomentation organs can support the incubated in the participation of technical visits, in workshops, conferences, associations and any other means to increase social insertion, favoring the creation of lasting ties. These ties also can be reinforced by the use of formal mentoring programs. The incubator manager can be a mentor, the most experienced business man, the researcher, the accountant, the lawyer, or any other actor with the capacity to perform the mentoring role.

The incubators also are characterized by the constant entrance and exit of their enterprises in the incubator program. From the perspective of the incubated that remain in the incubator, the ones that exit carry important contacts. In a way, the entrepreneurs who stayed should try to keep ties with their former-colleagues. This way, future research can provide important data on the shared meanings found in social networks even by questioning the former-incubated entrepreneurs or the persons in their network, even though, they are external to the incubator.

\section{References}

Arthur, M. B.; Hall, D. T.; Lawrence, B. S. (1989). "Generating new directions in career theory: the case for a transdisciplinary approach". In Arthur, M. B.; Hall, D. T.; Lawrence, B. S. (Eds.) Handbook of career theory, pp. 7-25, Cambridge: Cambridge University Press.

Baron, R. A. (1998). "Cognitive mechanisms in entrepreneurship: Why and when entrepreneurs think differently than other people." Journal of Business Venturing, 13, pp. 275-294.

. (2000) "Counterfactual thinking and venture formation: The potential effect of thinking about "what might have been." J ournal of Business Venturing, 15, pp. 79-92.

Bastos, A. V. B. (2001). "Cognição e ação nas organizações". In Davel, E. and Vergara, S. (Eds.). Gestão com pessoas e subjetividade. São Paulo: Atlas.

. (2002). “Mapas cognitivos e a pesquisa organizacional: explorando aspectos metodológicos". Estudos de psicologia. Natal, RN, v. 7, special number.

. (2000). "Mapas cognitivos: ferramentas de pesquisa e intervenção em processos organizacionais". Anais: Encontro Nacional de Estudos Organizacionais. Associação Nacional de Pós-Graduação e Pesquisa em Administração. Curitiba - PR, jun.

Baum, R. J., Locke, E. A.; Smith, K. G. (2001). "A multidimensional model of venture growth". Academy of Management J ournal, 44(2), 292-303.

Conner, K. R.and Prahalad, C. K. (1996). "A resource-based theory of the firm: knowledge versus opportunism". Organization Science, 7: 477-501. 
Creswell, J. W. (1994). Research design: qualitative \& quantitative approaches. Thousand Oaks: Sage.

Durkheim, E. (1997/1977). Suicide: a study in sociology. New York: Free Press.

Dyer Jr., W. G. (1994) "Toward a theory of entrepreneurial careers". Entrepreneurship Theory and Practice. Winter.

Eby, L. (1997). "Alterative forms of mentoring in changing organizational environments: a conceptual extension of the mentoring literature". Journal of Vocational Behavior. 51, pp. 125-144, doi: 10.1006/jvbe.-1594.

Fischer, F. M.; Oliveira, D.C.; Teixeira, L.R.; Teixeira, M.C.; Amaral, M. A. (2003). "Efeitos do trabalho sobre a saúde de adolescentes". Ciência e Saúde Coletiva, 8(4): 973-984.

Gartner, W. B. (1988). "Who is an entrepreneur: is the wrong question". American journal of small business, 13, Spring, pp.11-32.

Guba, E. G. ; Lincoln, Y. S. (1994). "Competing paradigm in qualitative research". In: Denzin, N. K. ; Lincoln, Y. S. (Eds.). Handbook of qualitative research. London: Sage, Cap. 6, pp. 105-117.

Higgins, Mônica C. \& Kram, Kathy E. (2001). “Reconceptualizing mentoring at work: a developmental network perspective". Academy of Management Review. V. 26 , no 2, p. 264-288.

Huff, A. S. (1990) (Ed.). Mapping strategic thought. New York: John Wiley and Sons.

Inkpen, A. C.; Tsang, E. W. K. (2005) "Social capital, networks, and Knowledge transfer". Academy of Management Review. Vol. 30, No. 1, pp. 146-165.

Kostova, T.; Roth, K. (2003). "Social capital in multinational corporations and a micro-macro model of its formation". Academy of Management Review. 28: 306324.

Kram, K. E. (1985). Mentoring at work: development relationships in organizational life. Glenview. IL: Scott, Foresman.

Laukkanen, M. (1992). Comparative cause mapping of management cognitions. Helsinki: Helsinki School of Economics.

Levinson, D. J.; Darrow, C. N.; Klein, E. B.; Levinson, M. A.; Mckee, B. (1978). Seasons of a man's live. New York: Knopf.

Machado-da-Silva, C. L., Fonseca, V. S., Fernandes, B. H. R. (2000). “Cognição e Institucionalização na Dinâmica da Mudança em Organizações". In. Rodrigues, S. B.; Cunha, M. P. Estudos Organizacionais: Novas Perspectivas na Administração de Empresas: uma coletânea luso-brasileira. São Paulo: I glu Editora, pp. 123-150.

Mariz, L. A , Goulart, S., Dourado, D., Régis, H. (2004). “O Reinado dos Estudos de Caso em Teoria das Organizações: Imprecisões e Alternativas". Anais: Encontro Nacional de Estudos Organizacionais. Atibaia-SP, jun. 
Mayrhofer, W., Meyer, M., Steyrer, J., lellatchitch, A., Schiffinger, M., Strunk, G., Erten-Buch, C., Hermann, A. and Mattl, L. (2002). "Einmal gut, immer gut? Einflussfaktoren auf karrieren in ,neuen' karrierefeldern“. Zeitschrift für personalforschung. 16. Jg., Heft 3.

Mitchell, R. K.; Busenitz, L.; Lant, T.; McDougall, P. P..; Morse, E; Smith, J. B. "Toward a theory of entrepreneurial cognition: rethinking the people side of entrepreneurship research." Entrepreneurship Theory and Practice, 27 (2), 2002.

Monge, P. R.; Contractor, N. S. (2003). Theories of communication networks. Oxford University Press: New York.

Nicolini, D. (1999). "Comparing methods for mapping organizational cognition". Organization Studies, 20(5), 833-860.

Nonaka, I.; Takeuchi, H. (1997). Criação de conhecimento na empresa. Rio de Janeiro: Campus.

Regis, H. P. (2005). "Construção social de uma rede informal de mentoria nas incubadoras de base tecnológica do Recife". Tese de Doutorado. Programa de PósGraduação em Administração. Universidade Federal de Pernambuco, Recife.

Robinson, P. B.; Stimpson, D. V.; Huefner, J. C.; Hunt, H. K. (1991). "An attitude approach to the prediction of entrepreneurship". Entrepreneurship theory and practice, 15(4), pp. 13-32.

Rousseau, D. (1997). “Organizational behavior in the new age". Annual Review of Psychology, v. 48, pp. 515-546.

Sá, C. P. (1996). Núcleo central das representações sociais. Petrópolis: Vozes.

Sexton, D. L.; Bowman, N. B. (1984). "The effects of preexisting psychological characteristics on new venture initiations". Paper presented at the Meeting of the Academy of Management, Boston, Massachusetts.

Schein, E. H. (1978). Career dynamics: matching individual and organizational needs. Reading, MA: Addison-Wesley.

Shane, S. (2000). "Prior knowledge and the discovery of entrepreneurial opportunities". Organization Science, 11, 448-469.

Shaver, K. G.; Scott, L. R. (1991). "Person, process, choice: the psychology of new venture creation". Entrepreneurship theory and practice, 16(2), 23-46.

Sullivan, R. (2000). "Entrepreneurial learning and mentoring". I nternational J ournal of Entrepreneurial Behaviour \& Research, vol. 6 n.3. University Press, pp. 13552554.

Vergara, S. C. (2005). Métodos de pesquisa em administração. São Paulo: Atlas.

Weick, K.; Bougon, M. G. (1986). “Organizations as cognitive maps: charting ways to success and failure". In: Sims, H. P.; Gióia, D. A. The thinking organization. São Francisco: Jossey-Bass. 
Wellman, B. (1992). "Which types of ties and networks provide what kinds of social support?" In Lawler, E. J. (Ed.) Advances in group processes. Vol. 9., pp. 207-235. Greenwich, CT: JAl.

Yin, R. K. (2001). Estudo de caso: planejamento e métodos. 2. ed. Porto Alegre: Bookman.

Zajonc, R.; Wolf, D. (1966). "Cognitive consequences of a person's position in a formal organization". Human relations, 19, pp. 130-150. 